\title{
Correlation between two commercially available PMP-compliant particle number counting systems
}

\begin{abstract}
As a result of increased concern over the toxicological effects of particulate matter (PM) emitted by compression ignition vehicles, the European Union (EU) has introduced a particle number (PN) limit. This represents a significant departure from the traditional gravimetric approach of quantifying PM emissions, and introduces unique challenges to the automotive testing process. The legislation sets certain limits and guidelines for systems designed to quantify particle number emissions, but the legislation currently has some flexibility regarding system layout, operating temperatures, etc. In this work, two commercially available particle counting systems were tested with a variety of Euro 5 light-duty CI vehicles equipped with particulate filters (DPFs). The results indicate a small but reasonably consistent discrepancy between the two systems, with a mean difference of $9.3 \%$. Possible causes of this difference (which was not observed in all cases) are discussed in the context of the current EU light-duty CI PN limit, and possibilities for future research directions are suggested.
\end{abstract}

Key words: exhaust emission, particulate matter, PMP-compliant

\section{Korelacja wyników pomiaru liczby cząstek stałych za pomocą dwóch systemów zgodnych z wymaganiami protokołu PMP}

\begin{abstract}
Jako rezultat rosnacego zainteresowania toksycznymi właściwościami czastek stałych (PM) emitowanych z silników o zapłonie samoczynnym, Unia Europejska wprowadzila dodatkowe limity dotyczace liczby emitowanych czastek statych $(P N)$. Metodyka pomiaru ilości emitowanych czastek różni się znacznie od tradycyjnego wagowego pomiaru emisji PM $i$ wprowadza nowa, unikalna procedure pomiarowa do znanych metod badania emisji zwiąków szkodliwych spalin. Przepisy prawne wprowadzity limity dotyczace liczby emitowanych cząstek $i$ wymagania dotyczace konstrukcji uktadu pomiarowego do określania tej liczby - te nowo wprowadzone przepisy cechuje pewna elastyczność w zestawieniu aparatury pomiarowej, temperatury pomiaru i innych parametrów.

$W$ artykule opisano porównanie wyników pomiarów liczby cząstek statych uzyskanych przy u̇̇yciu dwu systemów pomiarowych, pochodzacych od różnych producentów, przy badaniu wielu samochodów z silnikami ZS, spetniajacych wymagania Euro 5 i wyposażonych w filtry czastek stałych (DPF). Uzyskane wyniki pokazały nieduze, lecz jednak znaczace różnice w liczbach cząstek zmierzonych przy użyciu obu przyrząów - do około 9,3\%. Możliwe przyczyny tych różnic (które jednak nie wystęuja przy każdym pomiarze) przedstawiono i omówiono w kontekście obecnie obowiazujących limitów PN dla silników ZS w przepisach Unii Europejskiej. Zaproponowano również zakres dalszych analiz dotyczących tego problemu badawczego i planowanych do przeprowadzenia.
\end{abstract}

Słowa kluczowe: emisja spalin, cząstki stałe, protokót PMP

\section{Introduction}

The compression ignition $(\mathrm{CI})$ engine has become an increasingly common feature of light-duty vehicles over the past few decades. However, the increasing popularity of this engine type has been paralleled by growing concern over particulate matter (PM) emitted from vehicles featuring this type of engine. In urban settings, light- and heavy-duty road vehicles with CI engines are responsible for a large proportion of the anthropogenic PM load, and their massbased PM emissions have been restricted in the EU since 1992. From the Euro 1 standard to the Euro 5 standard, the gravimetric PM limit was reduced $>95 \%$, to a point where accurate quantification became difficult, as the legislative limit approached the detection limit for the specified method. Toxicological studies have revealed that health effects are more closely related to particle number and surface area

\section{Wprowadzenie}

W ostatnich kilku dekadach obserwowano znaczący wzrost udziału silników o zapłonie samoczynnym (ZS) we flocie samochodów osobowych na drogach Unii Europejskiej. Zwiększenie udziału silników ZS spowodowało zwiększenie emisji cząstek stałych (PM) z samochodów wyposażonych $w$ te silniki. Zarówno samochody osobowe, jak i ciężarowe z silnikami ZS mają znaczący udział w antropologicznym zanieczyszczeniu środowiska cząstkami stałymi, dlatego od 1992 r. ich emisja jest limitowana w krajach Unii Europejskiej. W stosunku do normy Euro 1 dopuszczalna emisja czastek stałych jest zmniejszona w normie Euro 5 o ponad 95\%. Dokładne określenie emisji cząstek staje się trudne, ponieważ dopuszczalne wartości ustalone w przepisach zbliżyły się do granicy wykrywalności. Ze studiów literaturowych wynika, że liczba cząstek stałych 
( $\propto$ diameter) than mass. As a result of these two factors, a particle number limit was introduced in Euro 5+ legislation for CI engines. This emissions limit represents a significant departure from previous requirements, as the measurement technique is fundamentally different from the methods employed to quantify gaseous and PM mass emissions.

Condensation particle counters (CPCs) have been used in a variety of applications for some time to monitor realtime, total or mean particle counts from various sources. In response to the upcoming requirement, multiple manufacturers of automotive emissions testing equipment began to market PMP-compliant particle counting systems suitable for testing light-duty vehicles for conformity with the demands of [1] and [2]. In addition to legislative requirements, particle counting systems are essential pieces of equipment for assessing the performance of PM aftertreatment systems (Diesel particulate filters, DPFs) for research and development work, as the gravimetric PM technique is insufficiently sensitive to distinguish between DPF-filtered PM emissions in most cases [3, 4]. Moreover, the gravimetric PM limit and the PN limit are not equivalent, the PN limit being considerably more stringent, thereby making particle counting the critical research metric for CI engines and aftertreatment systems [3].

Due to the relative paucity of data on correlations between the results generated by these devices, an experimental programme was carried out to assess the agreement between the two systems when tested in parallel.

A vehicle which emits particles at the Euro 5+ limit of $6.00 \times 10^{11} \# / \mathrm{km}$ will emit a total of around $6.60 \times 10^{12}$ particles over the duration of the NEDC, corresponding to a mean emission factor of hundreds of millions of particles for each metre of the cycle. Thus, particle number emissions are best represented as exponentials, to no more than two decimal places, as the figures involved are many orders of magnitude larger than other parameters commonly encountered in automotive emissions testing.

\section{Particle counting systems tested}

As the focus of this study was the performance of two similar but distinct systems, attention should be drawn to the operational specifics of the two systems. Selected data of the two particle counting systems employed are presented in Table 1.

The operating and quantification principal of the two systems is identical. A size-selective sample is taken from the dilution tunnel, heated and diluted, treated at high temperature to evaporate volatiles (non-solid phase particles), further diluted and cooled, and then drawn into the condensation particle counter unit. Here the sample is dosed with small quantity of butanol, which condenses onto the particles present to increase their size and ensure detection. A closely controlled volume of the sample is passed through a laser beam. The laser beam's interruption is detected using a series of lenses and a photometer, which generates a signal indicating particle detection. Both systems feature mathematical coincidence correction to i ich powierzchnia (określona na podstawie ich średnicy) mają większy, negatywny wpływ na zdrowie człowieka niż ich masa. W efekcie tego liczba cząstek stałych została objęta limitem w nowych przepisach Euro 5+ dotyczących silników ZS. Przepisy te znacznie różnią się od poprzednich metodyką pomiarową wyznaczania emisji związków gazowych i cząstek stałych.

Kondensacyjne liczniki cząstek stałych (CPCs - Condensation Particie Counters) od pewnego czasu są szeroko stosowane do pomiarów w czasie rzeczywistym całkowitej lub średniej liczby cząstek stałych emitowanych z różnych źródeł. Wychodząc naprzeciw przyszłym wymaganiom, wielu producentów aparatury do badań emisji związków szkodliwych spalin wprowadza obecnie na rynek aparatury pomiarowej systemy do pomiaru liczby cząstek stałych (zgodne z wymaganiami PMP), przeznaczone do badań samochodów kategorii M1 i N1 (pojazdów typu LDV), zgodne z wymaganiami przepisów zawartymi w [1] i [2]. W związku z wprowadzonymi limitami w regulacjach prawnych, systemy do wyznaczania liczby cząstek stałych w spalinach są obecnie podstawowym wyposażeniem laboratoriów badania emisji w celu oceny sprawności urządzeń oczyszczających spaliny z cząstek stałych (filtry cząstek stałych - DPF) w czasie prowadzonych prac badawczo-rozwojowych, ponieważ pomiar tylko masy cząstek stałych jest już obecnie niewystarczający $[3,4]$. Ponadto limity masy i liczby cząstek stałych nie są równoważne. Limit liczby cząstek jest bardziej restrykcyjny, co powoduje, że pomiar ten jest bardziej reprezentatywnym badaniem w przypadku silników ZS i ich układów oczyszczania spalin [3].

Ponieważ nie są publikowane informacje na temat korelacji wyników pomiarów uzyskanych z różnych urządzeń do pomiaru liczby cząstek stałych, zaproponowano badania pomiaru wartości PN, których celem było wyznaczenie korelacji między wynikami uzyskanymi z dwóch różnych systemów pomiarowych pochodzących od dwu różnych producentów, przy pomiarach wykonywanych równolegle.

Pojazd, dla którego emisja PN spełnia wymagania przepisów Euro 5+, gdzie dopuszczalny limit liczby cząstek stałych wynosi $6 \times 10^{11} \mathrm{~km}^{-1}$, który wyemituje około $6,6 \times 10^{12}$ cząstek stałych w całym teście NEDC, będzie średnio emitował kilkaset milionów cząstek stałych na każdy metr testu jezdnego. W związku z tym emisja PM wyrażana przez liczbę cząstek stałych jest najlepiej wyrażana przez funkcją potęgową, z nie więcej niż dwoma miejscami dziesiętnymi, ponieważ uzyskiwane wartości wyników w czasie takich pomiarów są wielokrotnie większe od innych parametrów typowo określanych przy badaniach emisji związków szkodliwych spalin.

\section{Opis dwu systemów do pomiaru liczby cząstek poddanych badaniom porównawczym}

Zgodnie z przedstawionym celem niniejszego opracowania, którym jest porównanie działania dwóch podobnych systemów do pomiaru liczby cząstek stałych, pochodzących od różnych producentów, szczególną uwagę zwrócono na sposób działania obu urządzeń. Podstawowe, wybrane 
Table 1. Key properties of the particle counting systems tested

Tabela 1. Podstawowe parametry porównywanych systemów do pomiaru liczby czastek stalych

\begin{tabular}{|c|c|c|}
\hline Parameter/parametr & System/system pomiarowy 1 & System/system pomiarowy 2 \\
\hline Manufacturer/producent & AVL & HORIBA \\
\hline Model & Particle Counter Advanced 489 & MEXASPCS-2000 \\
\hline Year of manufacture/rok produkcji & 2008 & 2010 \\
\hline Legislative basis/zgodność z wymogami & $\begin{array}{l}\text { PMP-compliant/zgodny; UN-ECE Reg. 83, } \\
\text { Annex 4a, Appendix } 5\end{array}$ & $\begin{array}{c}\text { PMP-compliant/zgodny; UN-ECE Reg. } 83 \\
\text { Annex 4a, Appendix } 5\end{array}$ \\
\hline Particle classifier & Performed by coniform sample probe & Performed by coniform sample probe \\
\hline PTS temperature & $150^{\circ} \mathrm{C}$ & $47^{\circ} \mathrm{C}$ \\
\hline VPR temperature & $\begin{array}{c}\text { Adjustable/regulowana } ; 350^{\circ} \mathrm{C} \text { setting used/ } \\
\text { podczas badań }\end{array}$ & $350^{\circ} \mathrm{C}$ \\
\hline $\mathrm{CPC}$ & TSI 3790 & TSI 3790 \\
\hline $\begin{array}{l}\text { Measurement range (to comply with legi- } \\
\text { slation)/zakres pomiarowy }\end{array}$ & $0-10000 \# / \mathrm{cm}^{3}$ & $0-10000 \# / \mathrm{cm}^{3}$ \\
\hline Working fluid/czynnik roboczy & n-butanol & n-butanol \\
\hline Control software & Manufacturer's own/producenta & Manufacturer's own/producenta \\
\hline
\end{tabular}

correct for the statistical probability of multiple particles impeding the laser beam at the same time (Fig. 1). Within certain limits, the application of coincidence correction increases the accuracy of the particle count, and for this reason it is required in the legislation [2]. The theoretical error inherent in the number counting process decreases logarithmically with particle concentration [7] (Fig. 1); at concentrations above a few hundred $\# / \mathrm{cm}^{3}$ the theoretical error becomes very low.

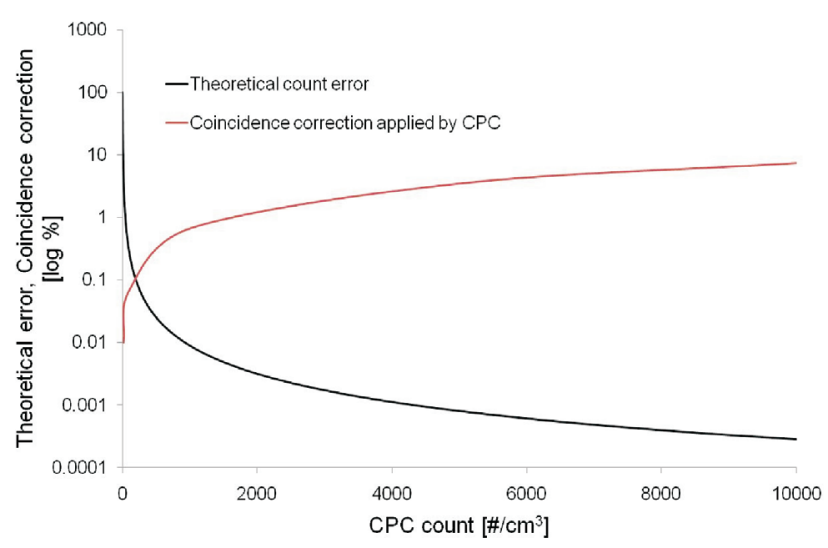

Fig. 1. Theoretical count error (after [7]) and $\mathrm{CPC}$ coincidence correc-

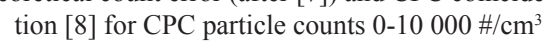

Rys. 1. Teoretyczny błąd pomiaru liczby cząstek statych i korekcja wykorzystywana w licznikach

The legislation allows for multiple system layouts and design concepts, provided certain criteria are met. A schematic of the recommended system layout is presented in Figure 2.

The key system components are: the particle transfer system (PTS), Particle Number Diluters $1 \& 2$ (PND1 \& PND2), the volatile particle reducer or evaporation tube (VPR, ET) and the condensation particle counter unit (CPC). parametry dwóch systemów użytych podczas badań przedstawiono w tabeli 1.

Zasada działania tych dwóch urządzeń do określania liczby cząstek stałych w spalinach jest taka sama. Próbka w czasie pomiaru była pobierana $\mathrm{z}$ tunelu rozcieńczającego spaliny powietrzem, który używa się również do pomiaru masy PM, była podgrzewana i rozcieńczana. Podgrzewanie próbki miało na celu odparowanie lotnych składników cząstek stałych; następnie próbka była rozcieńczana i schłodzona, a potem była kierowana do jednostki kondensacyjnej CPC. W skraplaczu do próbki dodawana jest niewielka ilość butanolu, który skrapla się na cząstkach, powodując zwiększenie ich średnicy i poprawę możliwości ich detekcji. Dokładnie określona objętość tak przygotowanej próbki jest przepuszczana przez wiązkę promieniowania laserowego. Przerwy w promieniowania wiązki lasera są wykrywane za pomocą soczewek i fotometru, który generuje sygnał informujący o wykryciu cząstki. Oba systemy wykorzystują matematyczne zależności określające statystyczne prawdopodobieństwo przejścia kilku cząstek przez wiązkę laserową w tym samym czasie (rys. 1). Wykorzystanie tych zależności powoduje zwiększenie dokładności wyznaczenia liczby cząstek stałych, dlatego w wymaganiach pomiarowych określonych w przepisach są podane granice wykorzystania tych zależności [2]. Błąd teoretyczny towarzyszący wyznaczaniu liczby cząstek stałych zmniejsza się logarytmicznie ze zwiększaniem koncentracji tych cząstek [7] (rys. 1); dla koncentracji powyżej kilkuset sztuk na centymetr sześcienny błąd teoretyczny jest już bardzo mały.

Wymagania przepisów dotyczących tego pomiaru umożliwiają wykorzystanie kilku koncepcji układów pomiarowych, pod warunkiem zachowania określonych wymagań. Schemat działania rekomendowanego urządzenia pomiarowego przedstawiono na rys. 2. Kluczowe komponenty układu są następujące: system przepływu cząstek (PTS - Particulate Transfer System), tunele rozcieńczające 1 i 2 (PND - Particulate Number Diluters), reduktor cząstek 


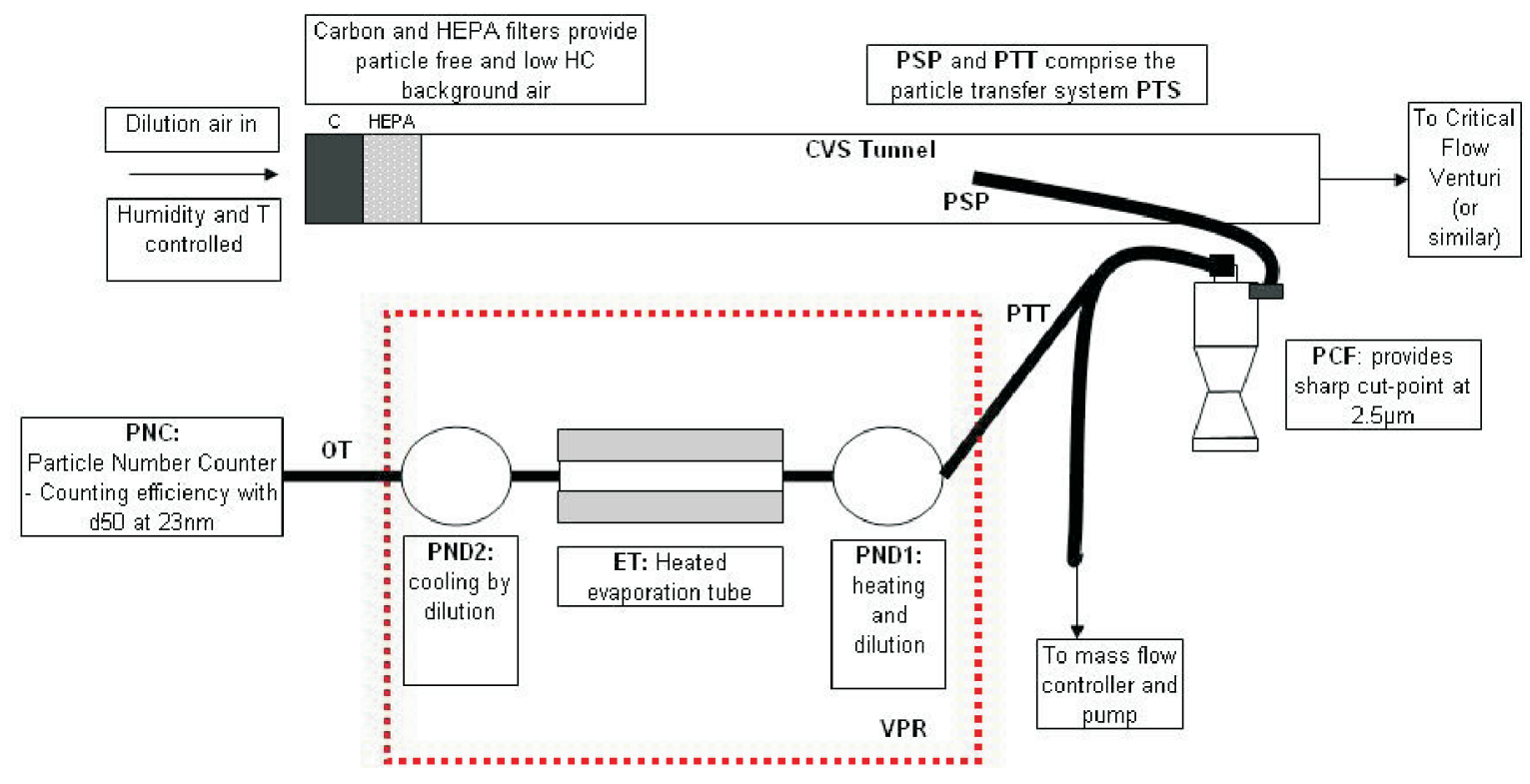

Fig. 2. Recommended system layout for quantification of solid particles [2]

Rys. 2. Schemat rekomendowanego systemu do pomiaru liczby czastek stalych

The main difference between the two systems used in this study lies in the sample handling approach. System 1 features its PND1 immediately downstream of the sampling probe, mere centimeters from the CVS tunnel. Here the sample is mixed with dilution air at a temperature of $150^{\circ} \mathrm{C}$, and the diluted sample is then conveyed onwards to the ET. In contrast, System 2 does not feature its PND1 diluter in the sample line. The sample is conveyed through a heated sample line (at $47^{\circ} \mathrm{C}$ ) to the instrument cabinet, where it passes through a heated orifice block, enters PND1 and then moves onwards to the VPR. Additionally, there are some differences between the two systems regarding the means by which the quantity of supplied dilution air is measured and controlled.

\section{Experimental programme}

A series of emissions tests were performed using two particle number counting systems in parallel, to obtain results suitable for direct comparison. Measuring with both systems simultaneously effectively eliminates the driver and the vehicle as sources of error, since any variation (e.g. vehicle oil temperature, fuel density, driver errors) will affect both systems. Since the context of the investigation was the quantification of PN emissions of light-duty vehicles for conformity with the Euro 5+ PN limit, DPF-equipped Euro 5 vehicles were used as a source of particulates. Three vehicles were used, two of which were tested with multiple aftertreatment systems, giving a total of 14 vehicle-ATS combinations. No dilution settings are specified in the legislation, however the dilution ratio must be sufficient to ensure that the maximum value read by the CPC is $\leq 10000 \# / \mathrm{cm}^{3}$ [2]. Any tests where the raw particle count exceeded this value were rejected and repeated using a higher dilution setting. Since the dilution settings of each instrument are discretely lotnych lub tunel odparowujacy (VPR - Volatile Particle Reducer, ET - Evaporation Tube), kondensacyjny licznik cząstek (CPC - Condensation Particle Counter).

Zasadnicza różnica między dwoma testowanymi urządzeniami polega na różnych systemach pobierania próbki do pomiaru. W systemie 1 tunel rozcieńczający (PND1) znajduje się bezpośrednio za miejscem poboru próbki, zaledwie kilka centymetrów od tunelu rozcieńczającego układu CVS. Spaliny są w nim mieszane z powietrzem w temperaturze $150{ }^{\circ} \mathrm{C}$ i dalej są przekazywane do tunelu odparowującego (ET). W drugim przypadku systemu tunel rozcieńczający PND1 nie znajduje się na drodze poboru spalin. Pobrana próbka spalin płynie przez podgrzewany przewód próbkujący $\left(47^{\circ} \mathrm{C}\right)$ do obudowy urządzenia, przechodzi dalej przez podgrzewaną zwężkę do tunelu rozcieńczającego PND1, a następnie do tunelu odparowania lotnych składników VPR. Występują jeszcze inne różnice pomiędzy tymi dwoma urządzeniami, które dotyczą sposobu określania pobieranego powietrza do rozcieńczania spalin i sterowania tym rozcieńczeniem.

\section{Program badań}

W ramach badań porównawczych wykonanych z użyciem dwóch systemów do pomiaru liczby cząstek stałych przeprowadzono serię testów emisji na hamowni podwoziowej w cyklach jezdnych NEDC. Urządzenia te były połączone równolegle, aby można było porównać uzyskane wyniki badań i wyeliminować wpływ takich źródeł błędów pomiaru, jak sposób jazdy kierowcy, zachowanie samochodu i praca silnika, temperatura oleju, gęstość paliwa itp., ponieważ celem prowadzenia pomiarów PN jest określenie poziomu tej emisji dla pojazdów spełniających wymagania Euro 5+. Do wykonywania testów emisji użyto pojazdów kategorii LDV, spełniających normę Euro 5 i wyposażonych w filtry 
(rather than continuously) adjustable, and since the dilution setting of System 1 is fixed at 10 and System 2 at 15, it is not possible to use the same dilution settings for both instruments. Within these constraints, the dilution settings of each instrument were selected to give dilution settings as close as possible (e.g. System $1=100$, System $2=150$; System $1=1000$, System $2=750$ etc.). An earlier study concluded that the dilution setting used had no significant effect on the particle count results, within certain limits [9].

Key characteristics of the three test vehicles are given in Table 2. cząstek stałych (DPF). Badania wykonano na trzech pojazdach, $\mathrm{z}$ których dwa były badane w różnych konfiguracjach, zależnie od zastosowanych układów oczyszczania spalin (zmienianych do kolejnych testów). W rezultacie dało to 14 różnych kombinacji samochód + układ DPF w czasie badań. Ponieważ w regulacjach prawnych nie ma wytycznych odnośnie do rozcieńczania spalin, współczynnik rozcieńczenia dobrano tak, aby maksymalna koncentracja cząstek stałych zmierzona przez CPC nie była większa niż $10000 \mathrm{~cm}^{-3}$ [2]. Odrzucono wyniki testów, a następnie powtórzono wszystkie testy, w których ta wartość koncentracji była przekroczona.

Table 2. Test vehicles

Tabela 2. Charakterystyki techniczne badanych pojazdów

\begin{tabular}{|l|c|c|c|}
\hline Parameter/parametr & Vehicle/pojazd 1 & Vehicle/pojazd 2 & Vehicle/pojazd 3 \\
\hline Vehicle type/rodzaj pojazdu & $\begin{array}{c}\text { Passenger car/ } \\
\text { samochód osobowy }\end{array}$ & $\begin{array}{c}\text { Passenger car/ } \\
\text { samochód osobowy }\end{array}$ & $\begin{array}{c}\text { Passenger car/ } \\
\text { samochód osobowy }\end{array}$ \\
\hline Approx. displacement/objętość skokowa silnika $\left[\mathrm{dm}^{3}\right]$ & 1.3 & 1.6 & 2.0 \\
\hline $\begin{array}{l}\text { Emissions standard/poziom emisji, aftertreatment/uktad } \\
\text { oczyszczania spalin }\end{array}$ & $\begin{array}{c}\text { Euro 5, close-coupled/ } \\
\text { zintegrowany reaktor } \\
\text { DOC }+ \text { DPF }\end{array}$ & $\begin{array}{c}\text { Euro 5, close-coupled/ } \\
\text { zintegrowany reaktor } \\
\text { DOC+DPF }\end{array}$ & $\begin{array}{c}\text { Euro 5, close-coupled/ } \\
\text { zintegrowany reaktor } \\
\text { DOC }+ \text { DPF }\end{array}$ \\
\hline $\begin{array}{l}\text { Number of aftertreatment systems tested/liczba przebada- } \\
\text { nych uktadów oczyszczania spalin }\end{array}$ & 1 & 5 \\
\hline
\end{tabular}

All vehicles were tested on a chassis dynamometer in BOSMAL's climate controlled laboratory (Fig. 3) (described in detail in [10]) over the well-known NEDC. Two particle counting systems were connected to the same dilution tunnel to be tested in parallel (Figs. 4, 5). Using the NEDC cycle and Type I test procedure provided a wide range of conditions for comparison of particle counts: cold start, warm-up during urban driving and finally high-speed highway conditions. Engine speed/load, and in-cylinder temperature affect

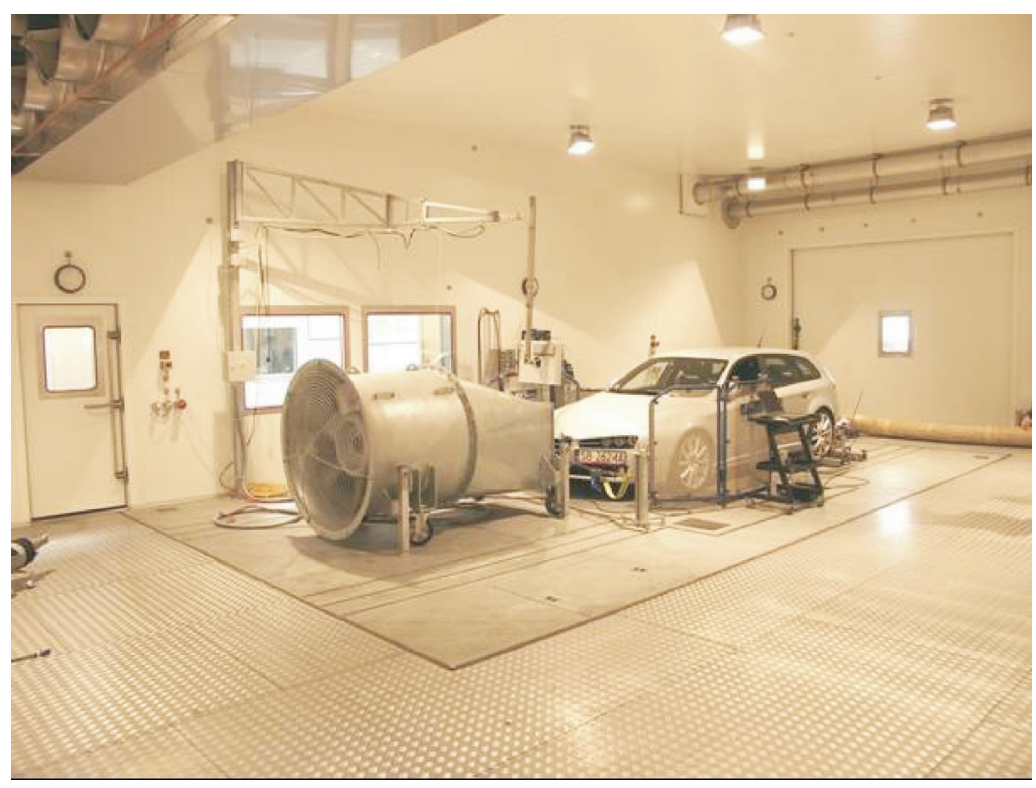

Fig. 3. BOSMAL's climate-controlled emissions testing laboratory, showing a vehicle mounted on the chassis dynamometer and the windspeed fan

Rys. 3. Laboratorium badania emisji z samochodem zamontowanym na hamowni podwoziowej $i$ z widocznym wentylatorem $w$ komorze klimatycznej Instytutu BOSMAL
Nie było możliwe wykonanie badań dla takich samych ustawień rozcieńczenia dla obu systemów pomiarowych ze względu na różny sposób regulacji tego rozcieńczenia dla przyrządów 1 i 2 . Ustawienia tego rozcieńczenia starano się dobrać tak, jak to było możliwe (np. System $1=100$, System $2=150$ oraz System $1=1000$, System $2=750$ itd.). Wcześniejsze doświadczenia wskazują jednak, że ustawienia te nie mają znaczącego wpływu na wyniki pomiarów, przy określonych limitach [9]. Zestawienie badanych pojazdów zamieszczono w tabeli 2.

Wszystkie badania wykonano podczas testu jezdnego NEDC, na hamowni podwoziowej w klimatyzowanej komorze laboratorium badania emisji Instytutu BOSMAL (rys. 3) (laboratorium opisano szczegółowo w pracy [10]). Oba systemy do pomiaru liczby cząstek stałych podłączone były bezpośrednio do tego samego tunelu rozcieńczającego (rys. 4 i 5) i pomiary prowadzono równolegle na obu urządzeniach. Cykl jezdny NEDC wykonywany według procedury typu 1 umożliwił uzyskanie wyników badań dla różnych warunków pracy silnika: zimny rozruch, nagrzewanie silnika w czasie jazdy miejskiej oraz jazda samochodu z dużymi prędkościami w czasie pozamiejskiej fazy testu. Prędkość obrotowa, obciążenie silnika oraz parametry przebiegu procesu spalania $\mathrm{w}$ cylindrze silnika, np. temperatura, mają istotny wpływ na emisję cząstek stałych, dlatego prowadzone badania mogły być adekwatne dla różnej emisji PN przy różnych stanach pracy silnika. Pomimo że głównym celem badań 


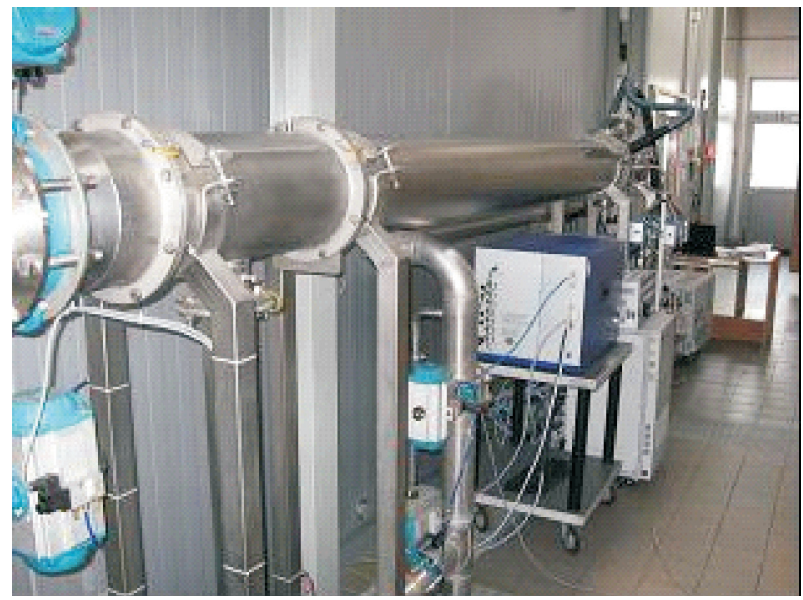

Fig. 4. Dilution tunnel downstream view, showing System 1 connected to the dilution tunnel

Rys. 4. Tunel rozcieńczający i system pomiarowy nr 1 podłaczony do tego tunelu

the properties of the particulates produced by the engine, and thus the tests performed permit evaluation of the two systems' quantification of a range of particulates. While the focus of the experiments was particle number emissions, modal emissions data were also measured and recorded, as was the PM mass. These 'traditional' emissions parameters were used as criteria to ensure repeatability between tests. Two to three tests were performed on each vehicle-ATS combination, using both particle counting systems.

\section{Results \& Discussion}

Small differences were observed between the two particle counting systems. Second-by-second traces and mean values obtained over the UDC, EUDC and NEDC all showed differences. The figures below show various comparisons between the results obtained using the two systems. Since the zero

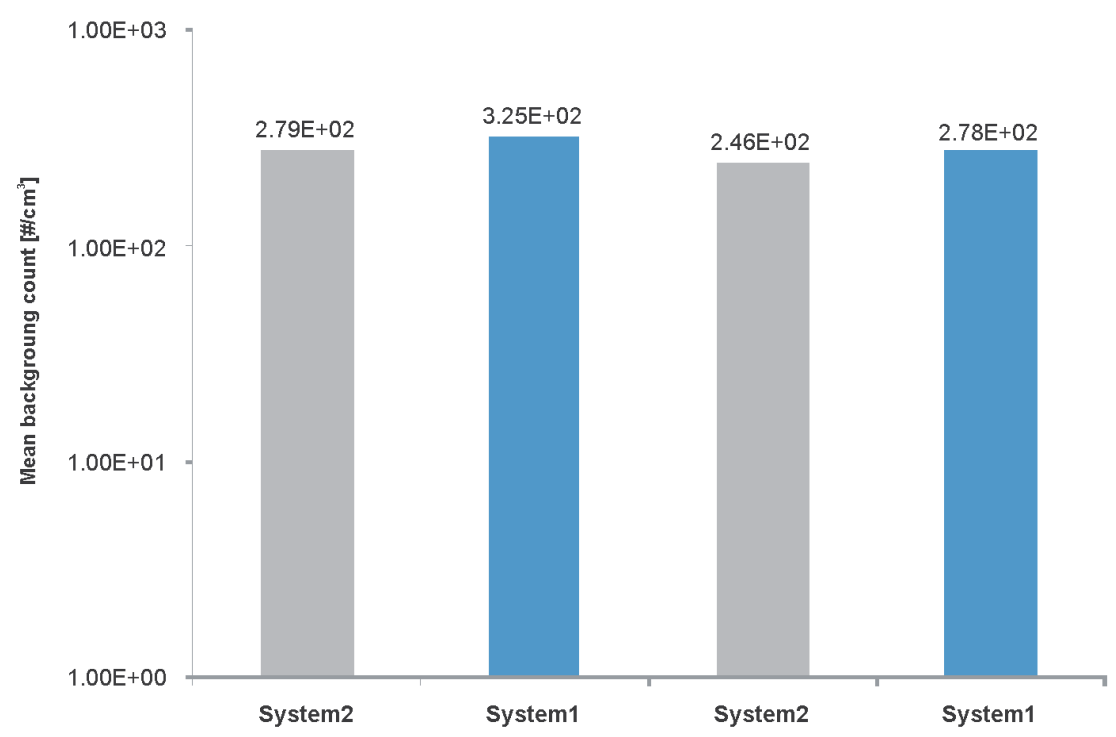

Fig. 6. Comparison of background readings for the two systems (each pair of readings taken a week apart during similar weather conditions with the same dilution settings)

Rys. 6. Porównanie zmierzonego tła pomiarowego dla obu systemów

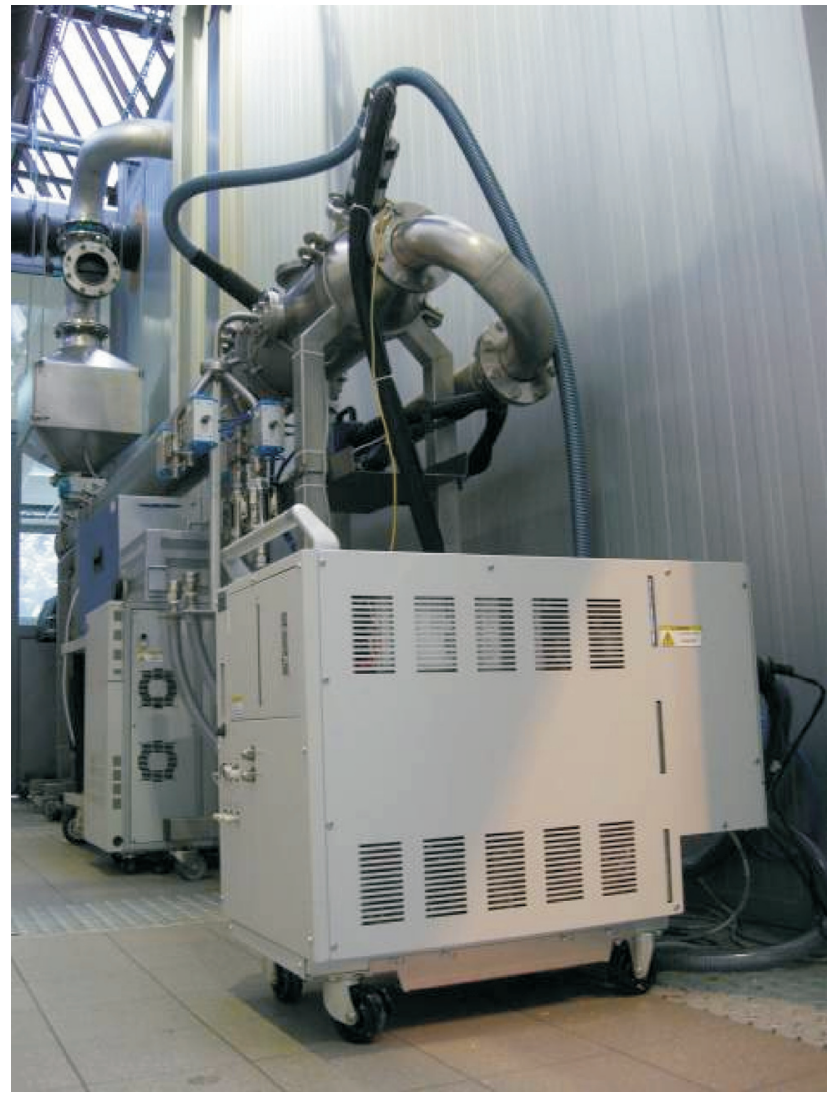

Fig. 5. Dilution tunnel upstream view, showing System 2 connected to the dilution tunnel

Rys. 5. Tunelu rozcieńczajacy i system pomiarowy nr 2 podłączony do tego tunelu

był pomiar liczby cząstek, wykonano także pomiary emisji związków gazowych oraz masy cząstek stałych PM. Emisja związków gazowych oraz masy cząstek stałych posłużyły jako kryterium oceny powtarzalności testów. Dla każdego obiektu badawczego (samochód + filtr cząstek stałych DPF) wykonano dwa lub trzy testy emisji, w czasie których mierzono liczbę cząstek PN przy użyciu obu porównywanych systemów pomiarowych.

\section{Wyniki badań $\mathrm{i}$ ich analiza}

Na podstawie uzyskanych wyników pomiarów stwierdzono, że wartości PN różnią się nieznacznie przy pomiarze wykonanym na obu urządzeniach pomiarowych. Różnice te są widoczne, gdy analizuje się wartości koncentracji PN w każdej sekundzie oraz średnie wartości dla całych cykli UDC, EUDC i NEDC. Przykładowe wyniki pomiaru koncentracji cząstek stałych dla obu systemów pomiarowych przedstawiono na rysunkach 6,7 i 8 . Ponieważ ustawienie ,0” , które jest niezbędne do codziennej kalibracji obu systemów, 
values (as given by the daily calibration procedures of the two systems) were very similar, the trendlines which appear in the figures below have been forced through the origin (i.e. $\mathrm{y}=\mathrm{mx}+0$ ).

The background readings of both instruments (taken with all particle number measurement systems active, but before cranking the engine) showed reasonable agreement, but with a tendency for System 1 to report higher values (Fig. 6).

Subjectively, on screen particle count traces appeared similar during testing (Fig. 7).

Particle number emissions were calculated using the same equation for both systems, as specified in the legislation [2]. Since the systems were connected to the same CVS, all variables in the calculation were identical, apart from each system's corrected particle count. An example of particle number emissions results from systems $1 \& 2$ is shown in Figure 8 and Table 3. These particular tests showed a good agreement, with limited differences in the results, but results from System 1 were higher in all cases. These differences between the two systems are relatively close to the differences reported in [3], but other results showed somewhat greater differences.

The cumulative particle count traces of both systems revealed similar trends but with a steadily increasing offset, as shown in Figure 9.

An example of the evolution of the ratio of the cumulative counts of both systems is shown in Figure 10. The first $\sim 60$

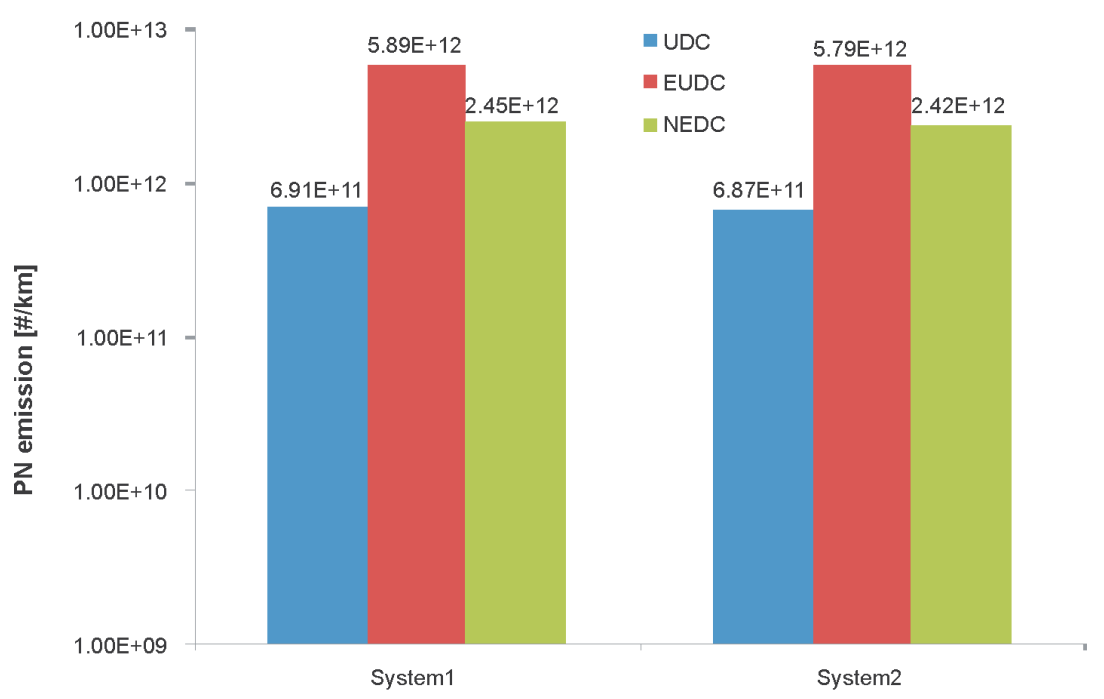

Fig. 8. PN emission factors, calculated according to [2], using mean particle count values from three tests performed on the same vehicle/ATS

Rys. 8. Wartości liczby czastek stałych wyznaczone zgodnie z [2]; wartości średnie wyznaczono dla trzech testów, dla tego samego pojazdu było bardzo zbliżone, linie trendu odnoszące się do poniższych wykresów były określone jako $\mathrm{y}=\mathrm{mx}+0$.

Odczytane tło pomiarowe dla obu urządzeń (pomiar koncentracji cząstek stałych wykonano dla unieruchomionego silnika, przed początkiem jego rozruchu) różniło się nieznacznie, większe wartości odczytano dla systemu 1 (rys. 6).

Przebieg zmian koncentracji cząstek stałych podczas testu jezdnego jest bardzo podobny dla obu użytych systemów pomiarowych (rys. 7).

Koncentracja cząstek stałych dla obu systemów była wyznaczona przy użyciu tych samych zależności opisanych w wymaganiach technicznych odnośnych przepisów [2]. Ponieważ oba systemy pomiarowe były podłączone do tego samego układu CVS, wszystkie zmienne potrzebne do obliczeń były takie same dla obu systemów, oprócz funkcji korygującej liczbę cząstek. Przykłady wyników pomiarów przedstawiono na rysunku $8 \mathrm{i} \mathrm{w}$ tabeli 3. Wyniki zamieszczone na rysunku 8 charakteryzują się małymi rozbieżnościami, jednak zauważono, że wartości dla systemu 1 są większe we wszystkich przypadkach. Różnice te są podobne do opisanych w pracy [3], natomiast pozostałe wyniki pomiarów różnią się już bardziej.

Skumulowany przebieg zmian koncentracji cząstek stałych dla obu systemów wykazuje podobną tendencję (rys. 9).

Przykład zmian wyznaczonego współczynnika (ilorazu) skumulowanej koncentracji liczby cząstek stałych ( $\sum$ system $2 / \sum$ system 1$)$ przedstawiono na rysunku 10 . W początkowych 60 sekundach testu zaobserwowano nieregularne zmiany tego współczynnika. Po około 180 sekundach testu wartości tego współczynnika stabilizują się i są dla trzech testów 
Table 3. PN emission factors, calculated according to [2], using mean particle count values from three tests performed on the same vehicle/ATS

Tabela 3. Wartości liczby czastek stałych wyznaczone zgodnie z [2]; wartości średnie wyznaczone dla trzech testów, dla tego samego pojazdu

\begin{tabular}{|l|c|c|c|}
\hline $\begin{array}{l}\text { Cycle/cykl } \\
\text { jezdny }\end{array}$ & $\begin{array}{c}\text { Mean System 1 emission factor [\#/km]/ } \\
\text { średnia emisja PN na } 1 \mathrm{~km} \text { dla Systemu 1 }(\mathrm{n}=3)\end{array}$ & $\begin{array}{c}\text { Mean System 2 emission factor [\#/km]/średnia } \\
\text { emisja PN na } 1 \mathrm{~km} \text { dla Systemu 2 }(\mathrm{n}=3)\end{array}$ & $\begin{array}{c}\text { Difference/różnica } \\
{[\%]}\end{array}$ \\
\hline UDC & $6.91 \mathrm{E} 11$ & $6.87 \mathrm{E} 11$ & 0.65 \\
\hline EUDC & $5.89 \mathrm{E} 12$ & $5.79 \mathrm{E} 12$ & 1.82 \\
\hline NEDC & $2.45 \mathrm{E} 12$ & $2.42 \mathrm{E} 12$ & 1.60 \\
\hline
\end{tabular}

seconds of each test were characterised by chaotic fluctuations in the cumulative count ratio between the two systems. By around 180 seconds into the cycle, the ratio had stabilized and was thereafter similar for these three tests, with a mean ratio of 0.89 (i.e. an $11 \%$ difference) maintained for the remainder of the NEDC.

Particle count data from the first (UDC) and second (EUDC) phases, as well as the entire NEDC were compared. Each of these results (3 per test per system) were compared (Fig. 11). While most results lie close to the line $\mathrm{y}=\mathrm{x}$, a difference in the two datasets is visible.

Based on the particle counts obtained over the UDC, EUDC and NEDC from the two systems, a mean discrepancy of $9.3 \%$ was observed (System $1>$ System 2). The observed difference in the number counts between the two systems was relatively consistent, with $65 \%$ of tests performed showing a difference of 0 20\% (System $1>$ System 2). In a few instances, the reverse was observed (System $1<$ System 2), but this only occurred in around $15 \%$ of all tests performed. A brief review of studies comparing PMP-compliant particle counting systems [7] report differences of $\pm 27 \%$ and $\pm 20 \%$; the experimental results in [7] reveal a difference between two systems of $\pm 15 \%$. Given that identical systems from the same manufacturer show small differences in their results [11], it is to be expected that systems of different ages, designs and manufacturers exhibit some discrepancies in their results [7]. Even when using a single particle counter, the total repeatability from test to test has been calculated to be $\pm 8 \%$ [11]. Further investigations in

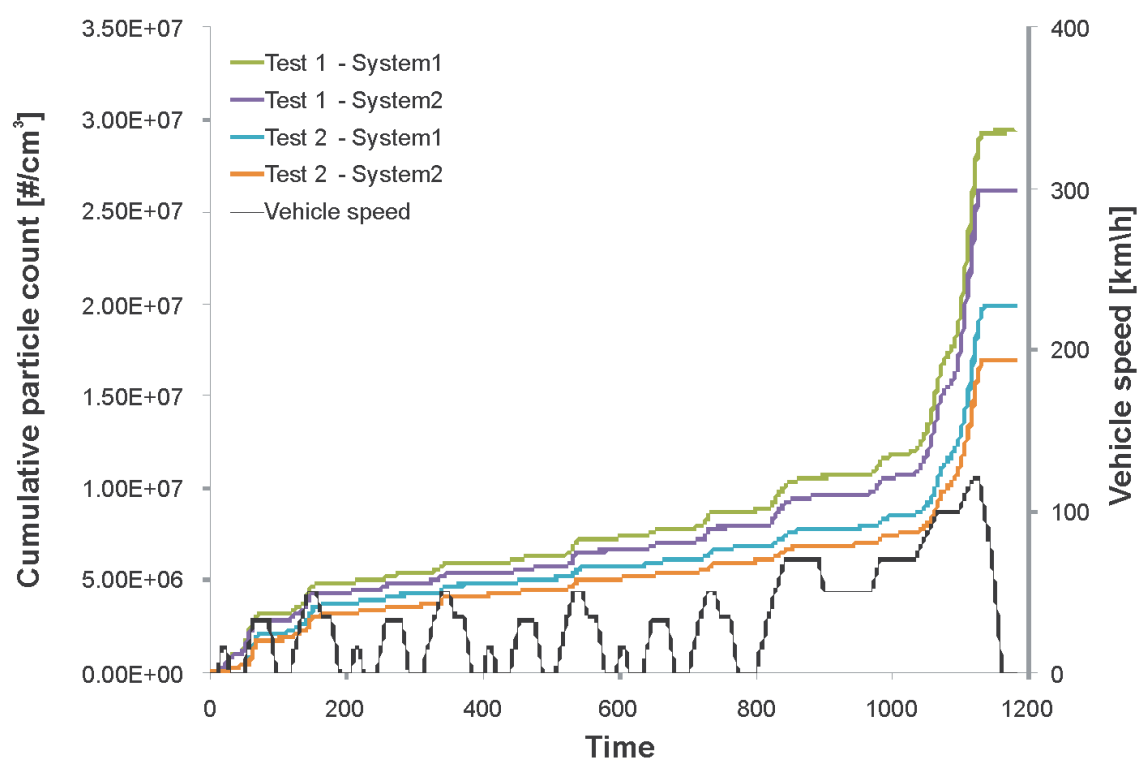

Fig. 9. Cumulative particle counts obtained during two tests on the same vehicle/ATS over the NEDC Rys. 9. Skumulowany przebieg zmian liczby cząstek stalych w teście NEDC dla dwóch pojazdów (po dwa testy dla każdego pojazdu)

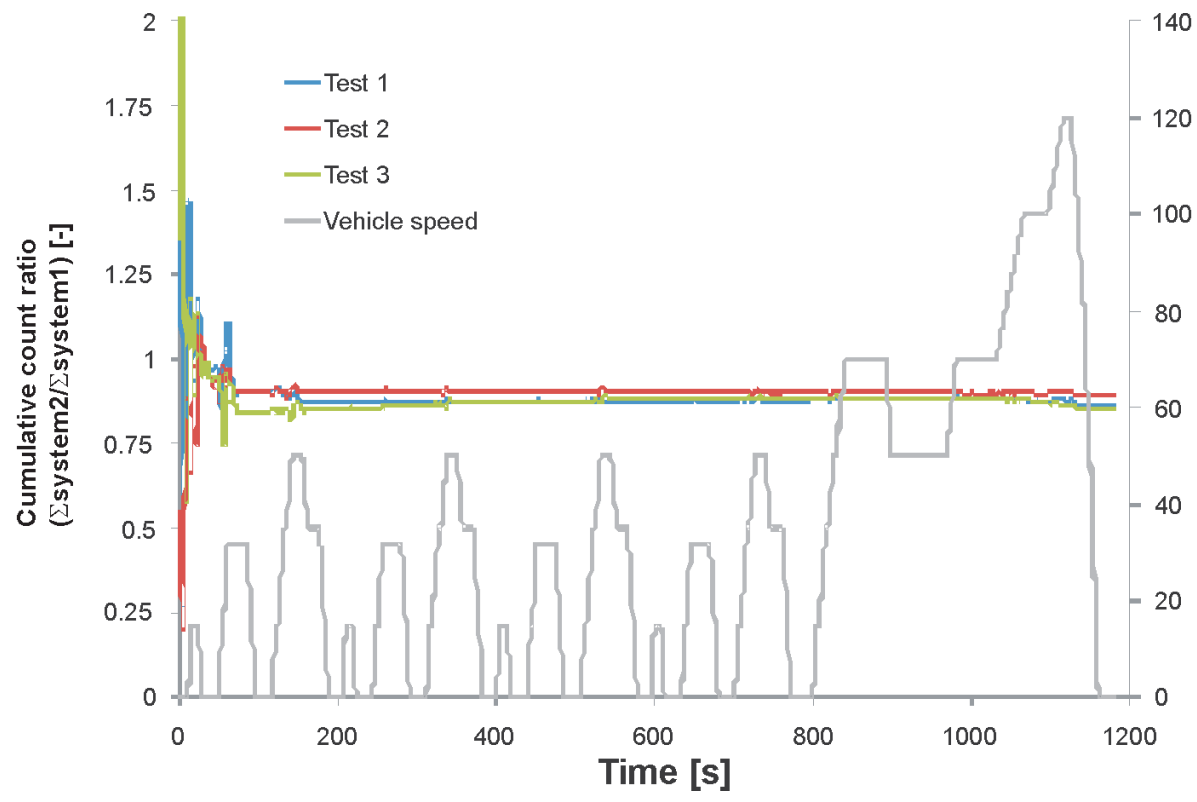

Fig. 10. A comparison of the ratio of the cumulative count of both systems for 3 tests performed on the same vehicle/ATS over the NEDC

Rys. 10. Porównanie współczynników skumulowanej koncentracji 


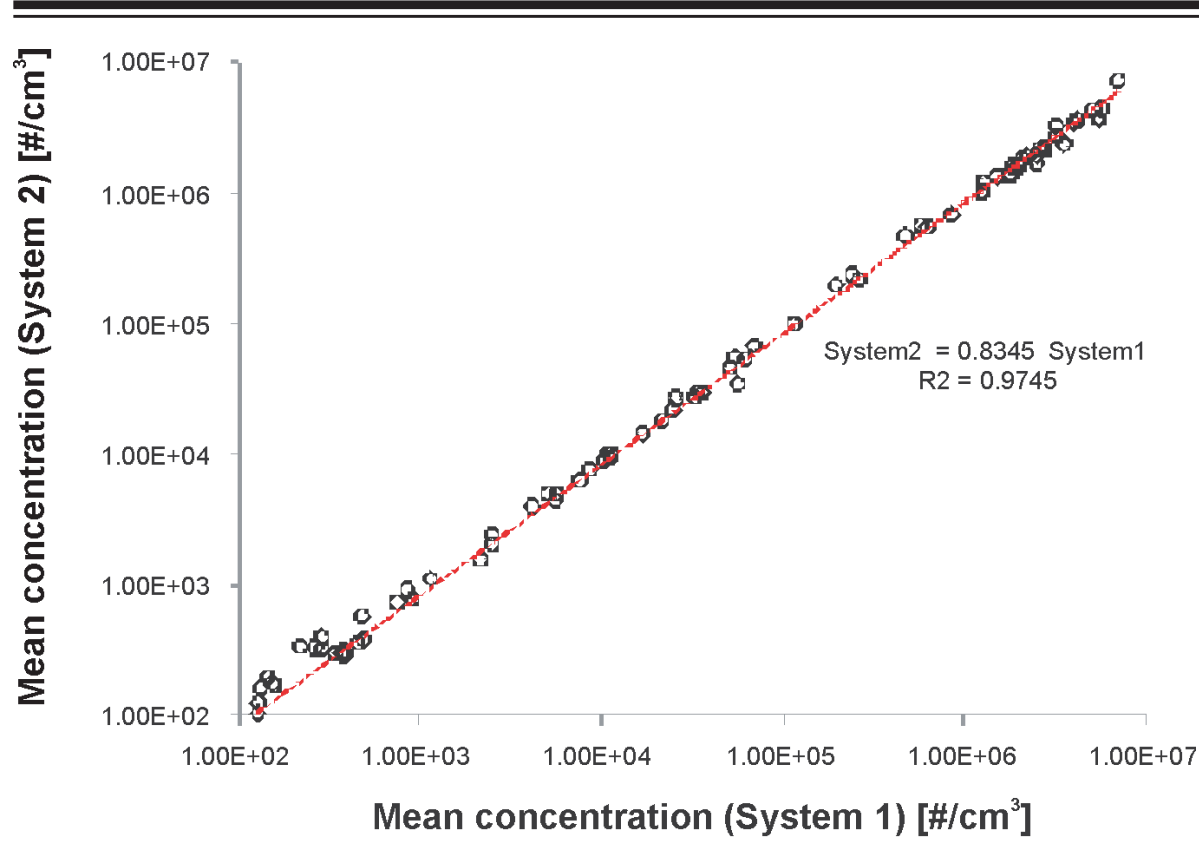

Fig. 11. A comparison of all collected data (UDC, EUDC, NEDC) from Systems 1 and 2 for all three tests vehicles and various ATS

Rys 11. Porównanie wyników badań (dla testów UDC, EUDC, NEDC) dla obu systemów 1 i 2 dla trzech badanych samochodów

this area would require testing two devices of the same type simultaneously for comparison of results - i.e. System 1 vs. System 1, System 2 vs. System 2. The results of such a test would be suitable for direct comparison to the discrepancies observed in the experimental work described here.

The difference in the particle counts between the two systems was not observed to correlate with any environmental parameter (ambient temperature, humidity, etc). The emission level (as determined by the vehicle in question and the

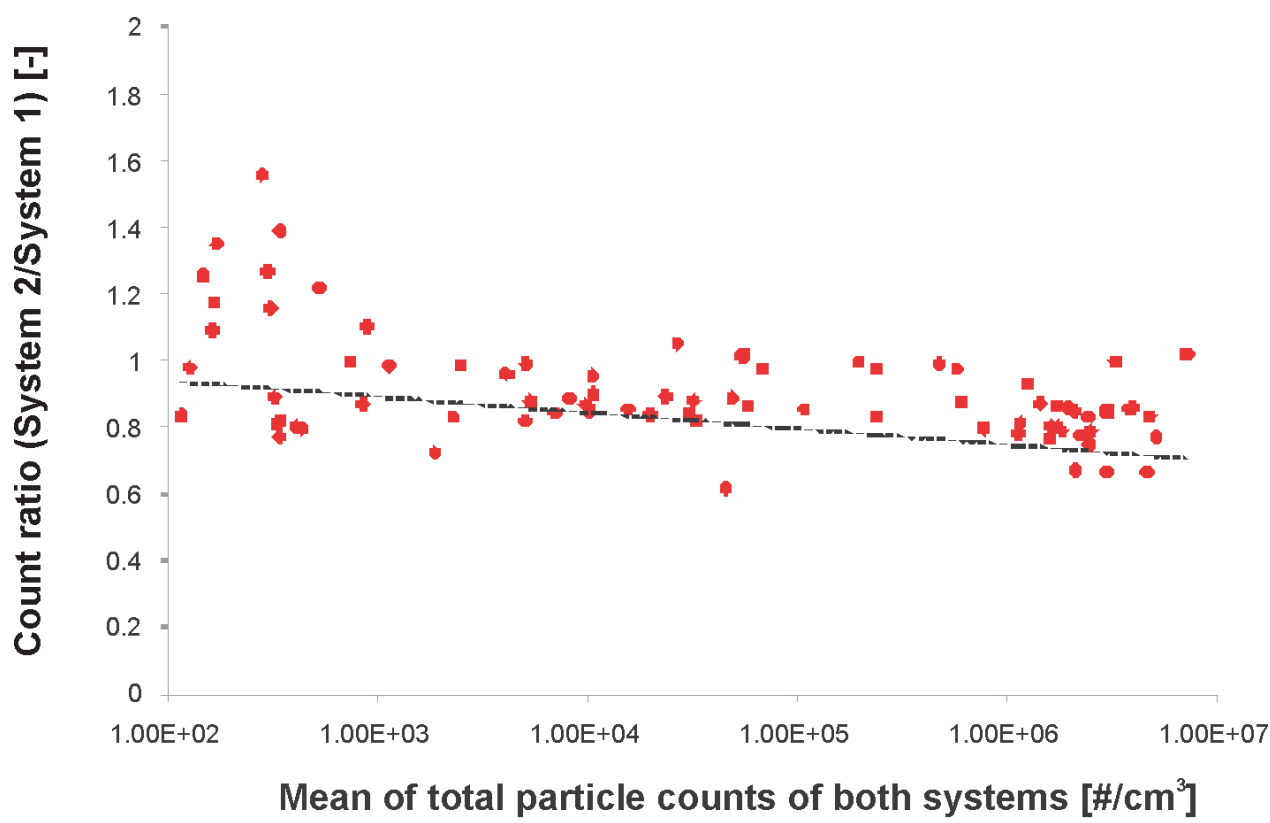

Fig. 12. Correlation between mean particle count obtained over the UDC, EUDC and NEDC and the difference in the two system's results

Rys. 12. Korelacja między średnia liczba cząstek stałych w testach UDC, EUDC i NEDC i różnica $w$ wynikach dla obu systemów
Porównano wyniki pomiarów dla obu faz testu UDC, EUDC oraz całego cyklu jezdnego NEDC. Stwierdzono, że między wynikami zachodzi duża korelacja i leżą one wzdłuż prostej funkcji opisanej równaniem $\mathrm{y}=\mathrm{f}(\mathrm{x})$ (rys. 11).

Bazując na wynikach uzyskanych w testach UDC, EUDC i NEDC dla dwóch systemów pomiarowych, odnotowano średnią rozbieżność na poziomie $9,3 \%$ (system $1>$ system 2). Dla 65\% wykonanych testów różnice mieszczą się w przedziale $0-20 \%$ (system 1> system 2). Tylko w nielicznych przypadkach, około $15 \%$ wykonanych testów, zaobserwowano odwrotną tendencję (tzn. system $2>$ system 1 ).

Krótka teoretyczna analiza porównawcza systemów pomiaru liczby cząstek stałych, zgodnych z wymaganiami PMP, zaprezentowana w pracy [7] wskazuje na możliwe różnice $\pm 27 \% \mathrm{i} \pm 20 \%$, natomiast $\mathrm{z}$ wykonanych badań porównawczych dwóch systemów wynika, że różnica wynosiła $\pm 15 \%$ [7]. Badania wykazały nieznaczne różnice między dwoma takimi samymi systemami tego samego producenta [11], jednak przy dwu systemach różniących się producentem, rokiem budowy i czasem użytkowania różnice w wynikach mogą być większe [7]. Nawet w czasie używania tylko jednego systemu pomiarowego PN powtarzalność wyników wynosi około $\pm 8 \%$ [11]. Dalsze badania w tym zakresie wymagałyby przeprowadzenia badań porównawczych dwóch urządzeń tego samego typu. Wyniki tak przeprowadzonych badań porównawczych mogłyby posłużyć do bezpośredniego oszacowania zaobserwowanych różnic pomiarów i analizy wyników opisanych w tej pracy.

Podczas wykonywanych badań nie zaobserwowano wpływu warunków otoczenia na uzyskane wyniki (temperatury otoczenia, wilgotności itp.), natomiast zaobserwowano zależność między średnią koncentracją cząstek stałych (w zależności od stopnia sprawności filtra cząstek DPF) a wskazaniami 
efficiency of the DPF fitted) was observed to correlate somewhat with the observed difference between the two systems' results (Figure 12). The mean of the two values returned by the systems can be used as a proxy for the 'real' value. The correlation shown in Fig. 12 indicates a gradual increase in discrepancy with increasing emissions, which is mathematically logical. This also suggests that any particle losses in System 2 were more severe at higher concentrations.

Following the observation of modest but consistent differences in the particle counts of the two systems, questions arise as to the origin of these discrepancies. A range of possible causes are considered and discussed below.

The close proximity and identical geometry of the sampling probes, and the high turbulence within the dilution tunnel can be assumed to negate any differences in the sample drawn into the systems' respective sampling probes. The quantification of volatile particles is particularly difficult, and substantial surface effects can occur in sampling systems [9]. Partially for this reason, the PN test procedure specified in the legislation deliberately excludes volatile particles, and both systems tested here featured a volatile particle remover operating at the same temperature setting $\left(350{ }^{\circ} \mathrm{C}\right)$, designed to ensure $>99.0 \%$ removal of $30 \mathrm{~nm}$ tetracontane particles, as required by the legislation [2]. The temperatures of both systems' VPRs were checked before commencing a test, and were monitored during the test; no significant fluctuations were observed. Thus, the contribution of any volatile particles to the total particle count is likely to have been very limited for both systems. However, the possibility that System1's VPR temperature sensor had suffered a small drift cannot be excluded. This could cause the VPR to operate at a slightly lower temperature, thereby allowing quantification of some volatile particles and increasing the total number count somewhat. The survival of volatile particles in the VPR has been calculated to cause limited discrepancies in the total particle count $(\leq 1.6 \%)$ [11], significantly smaller than the differences observed.

Following the rejection of these parameters as likely causes of the observed difference, the overall observation of slightly lower particle numbers in System 2 can perhaps be at least partially attributed to the aforementioned differences in the sample intake and dilution stages. One of the root causes of the difficulty of accurately quantifying $\mathrm{PN}$ is the fact that particles can be deposited not on the surfaces of sample transfer tubing, but also on the surfaces of other particles. It is a possibility that the relatively concentrated, lower temperature sample in System 2 suffered slightly greater particle losses while travelling to System 2's PND1, thereby reducing the number count somewhat. The transfer of an undiluted sample (containing particles with a shorter mean free path than those in a diluted sample) in System 2 gives an (admittedly brief) opportunity for agglomeration of particles, which would later reduce the number count somewhat. The difference in the temperature at which the two samples are conveyed through the sample tubing could have an impact on particle deposition processes through obu systemów pomiarowych. Średnią wartość uzyskaną z dwóch systemów przyjęto jako rzeczywistą koncentrację. Z zależności przedstawionej na rysunku 12 wynika, że ze zwiększaniem koncentracji cząstek stałych zwiększa się różnica między wskazaniami obu systemów. To oznacza również, że dla większej koncentracji cząstek stałych w spalinach dla systemu 2 odnotowano większe niedokładności pomiaru.

Wobec niezbyt dużej, ale systematycznie występującej różnicy wskazań dwóch systemów pojawia się pytanie o źródło tych różnic pomiarów. Poniżej przedstawiono krótką dyskusję na temat możliwych przyczyn tego zjawiska.

Ze względu na podobieństwo geometryczne sond pomiarowych i duże zawirowanie podczas przepływów turbulentnych można przyjąć, że nie ma różnic w przygotowaniu próbek spalin do pomiarów. Ze względu na możliwość wystąpienia w układzie poboru próbki efektu oddziaływania powierzchni ścianek, ilościowe określenie cząstek lotnych jest szczególnie trudne [9]. Jest to jeden z powodów, dla którego procedury pomiaru liczby cząstek stałych zawarte w przepisach wykluczają z pomiaru cząstki lotne. W obu systemach były reduktory cząstek lotnych i pracowały w tych samych temperaturach $\left(350{ }^{\circ} \mathrm{C}\right)$. Są one zaprojektowana tak, aby usunąć ponad $99 \%$ cząstek o średnicach $30 \mathrm{~nm}$; wymóg ten jest zapisany w regulacjach prawnych [2]. Temperatury pracy reduktorów cząstek lotnych (VPR) były sprawdzane przed rozpoczęciem pomiarów i monitorowane w ich trakcie - nie zaobserwowano znaczących odchyleń od założonych wartości. Z tego powodu udział cząstek lotnych w układzie pomiarowym dla obu systemów był bardzo mały. Jednak nie można wykluczyć nieznacznej zmiany sygnału pomiarowego czujnika temperatury układu redukcji lotnych cząstek systemu 1, co mogło spowodować niższą temperaturę pracy tego układu i w konsekwencji większą liczbę lotnych cząstek. Pozostanie cząstek lotnych w układzie VPR zostało obliczone w stosunku do całkowitej liczby cząstek (poniżej 1,6\%) [11]; wartość ta jest niższa od różnicy pomiarów obu systemów pomiarowych.

Mniejsze wskazania liczby cząstek stałych dla systemu 2 mogły być spowodowane wspomnianymi wyżej różnicami w przygotowaniu próbek spalin i rozcieńczeniem. Inną przyczyną mogło też być osadzanie cząstek nie na ściankach drogi pomiarowej, ale na powierzchniach innych cząstek. Jest możliwe, że z powodu niższej temperatury w systemie 2 mniejsza liczba przetransportowanych cząstek trafiała do pierwszego stopnia rozcieńczenia. Przepływ nierozcieńczonej próbki w systemie 2 umożliwił aglomerację cząstek stałych i w związku z tym zmniejszenie ich liczby. Różnica temperatur, w jakich próbki były transportowane w układzie pomiarowym mogła mieć wpływ na osadzanie, co mogło być spowodowane efektem polegającym na „odpychaniu” cząstek od ścianek przewodu, które miały wyższą temperaturę od przepływającego czynnika (spalin). Efekt ten mógł także wystąpić w liczniku, ponieważ średnica cząstek jest odwrotnie proporcjonalna do prędkości ruchu wynikającego $\mathrm{z}$ różnicy temperatury [13]. Występowanie przyrostu temperatury mogło wpływać również na próbkowanie [11]. Różnica temperatury między próbką spalin a ściankami 
thermophoretic effects, since particles are repelled from boundary walls which are at a higher temperature than the fluid in which they are carried [12]. Moreover, where this effect occurs, it can also act as a size classifier, as particle diameter is inversely proportional to thermophoretic velocity [13]. The existence of any type of temperature gradient can affect the sample through these thermophoretic effects [11]. The difference in the temperature of the sample taken from the dilution tunnel and the sample tubing is around $115^{\circ} \mathrm{C}$ in the case of System 1 and around $12^{\circ} \mathrm{C}$ in the case of System 2. These differences could be a plausible explanation for the particle count differences of the magnitude observed. The small but relatively consistent discrepancy reported here is worthy of further investigation. Performing a size classification of the particulates present in the exhaust would provide further information on likely particle desposition/sample loss mechanisms. Additionally, the particles present in each system's output (sample return route) could be investigated, to further investigate particle losses within the two systems. Furthermore, the existence of long-term trends in the results produced by System 2 will be assessed as this system accrues operating hours. In order to fully determine particle losses and the responsiveness of the two systems, a steady particle source could be used to provide particles of known diameter to the two systems, so that $\Sigma$ system $2 / \Sigma$ system 1 could be calculated for a range of particle diameters. These investigations and their results and implications will be described in more detail in future publications in this journal.

\section{Conclusions}

Given the notorious difficulty in accurately quantifying total particle emissions from a fluctuating source (such as a CI engine operating in transient mode), the differences in the results obtained using the two systems tested here are relatively small, especially given the difference in accrued operating hours between the two systems. In some instances, test-to-test variation using the same vehicle and counting system was observed to be greater than the difference between systems $1 \& 2$. A large number of factors can influence particle number emissions, even over a defined legislative test cycle in a controlled laboratory environment, but it appears that the selection of either of the two particle counters used in this study will exert a much smaller influence than other factors. It is recognized as an unfortunate but as yet unavoidable fact that errors involved in the measurement of particulates are larger than those involved in measuring gaseous components [11]. At the current particle number limit, usage of either System 1 or System 2 exerts a limited impact on results. The Euro 6 proposal currently has the same PN limit as Euro 5+ $\left(6.00 \times 10^{11} \mathrm{\#} / \mathrm{km}\right)$, and it is unclear whether this limit will be reduced in the next round of light-duty emissions legislation. If the limit were reduced, the small difference between the two systems reported here would become somewhat more significant. In the longer term, if the PN limit was significantly reduced (e.g. $6.00 \times 10^{10} \# / \mathrm{km}$ ), this might require a more closely-specified particle counting setup and przewodu, przez który ona przepływa wynosi około $115^{\circ} \mathrm{C}$ dla pierwszego systemu oraz $12^{\circ} \mathrm{C}$ dla systemu 2 . Wskazane różnice wydają się wiarygodnym wytłumaczeniem zaobserwowanych wskazań liczników cząstek. Jednakże badania opisane w niniejszym artykule nie tłumaczą jednoznacznie przyczyn, natury i lokalizacji źródła zaobserwowanych różnic wskazań pomiarowych. Stosunkowo mała, ale relatywnie powtarzająca się różnica w pomiarach opisana powyżej powinna być przedmiotem dalszych analiz. Występowanie cząstek o różnych średnicach w spalinach na wylocie z każdego z tych dwu systemów pomiarowych mogłoby dawać dalsze informacje o mechanizmach odkładania się cząstek na ściankach przewodów i strat w czasie próbkowania. Dodatkowo, cząstki obecne na wylocie z każdego systemu (droga powrotna przy próbkowaniu) mogą być przedmiotem badań, aby dokładniej określić straty próbkowania w obu porównywanych systemach pomiarowych. W celu określenia całkowitych strat cząstek przy próbkowaniu i poprawności wskazań obu systemów źródło stałej emisji cząstek stałych, o znanej liczbie PN, mogłoby być użyte tak, by wytwarzać cząstki stałe o znanej średnicy, które byłyby następnie próbkowane przez oba porównywane systemy pomiarowe. Wtedy suma cząstek byłaby obliczana dla danej ich średnicy. Tego typu badania są obecnie prowadzone, a ich wyniki będą przedstawione $\mathrm{w}$ dalszych pracach dotyczących tej tematyki badawczej.

\section{Wnioski}

Biorąc pod uwagę opisane trudności z dokładnością wyznaczania liczby cząstek stałych $w$ warunkach dynamicznych, gdy podczas pracy silnika zmienia się jego prędkość i obciążenie, zaobserwowane różnice liczby cząstek stałych są nieduże, szczególnie gdy uwzględnimy różny okres ich użytkowania do prowadzenia pomiarów. W pewnych przypadkach badania powtarzane tym samym urządzeniem, na tym samym obiekcie dawały większe różnice niż te odnotowane przy pomiarach wykonywanych przez dwa testowane systemy. Na liczbę emitowanych cząstek stałych może mieć wpływ wiele czynników, również przebieg testu wykonywanego $\mathrm{w}$ warunkach laboratoryjnych, który jest opisany w regulacjach prawnych dotyczących pomiaru liczby cząstek stałych $\mathrm{w}$ spalinach. $\mathrm{Z}$ zaprezentowanych badań wynika, że zastosowanie któregokolwiek systemu pomiarowego ma mniejszy wpływ na uzyskane wyniki badań niż inne czynniki. Za niekorzystny efekt jest uznane również to, że błąd powstający w czasie pomiaru PN jest większy niż w czasie pomiaru poziomu emisji gazowych związków w spalinach. Uwzględniając obecny limit liczby cząstek stałych, użycie pierwszego lub drugiego systemu pomiarowego ma niewielkie znaczenie - są one porównywalne. W propozycji normy Euro 6 zapisano taki sam limit liczby cząstek stałych jak w normie Euro $5+\left(6 \times 10^{11} \mathrm{~km}^{-1}\right)$. Obecnie nie wiadomo, kiedy będzie on zmniejszony dla pojazdów LDV. Jednak, jeżeli limit ten będzie znacznie zmniejszony w przyszłości, to nawet niewielkie różnice zaobserwowane dla testowanych systemów pomiarowych mogą mieć już istotne znaczenie dla dokładności pomiarów. W dłuższej perspektywie, jeżeli limity liczby cząstek stałych zostaną znacznie zmniejszone (np. $6 \times 10^{10} \mathrm{~km}^{-1}$ ), może będzie to wymagało doprecyzowania 
test procedure: a proscribed system layout, uniform sample tubing lengths, fixed dilution settings, reduced temperature ranges, harmonized purging procedures, etc.

Paper reviewed/Artykut recenzowany specyfikacji urządzeń pomiarowych i testów pomiarowych, np. ujednolicenie długości przewodów poboru spalin, określenie współczynnika rozcieńczenia, zmniejszenie zakresu temperatury, ujednolicenie procedury przepłukania systemu pomiarowego itd.

\section{Bibliography/Literatura}

[1] Regulation (EC) No 715/2007 of the European Parliament and of the Council of 20 June 2007 on type approval of motor vehicles with respect to emissions from light passenger and commercial vehicles (Euro 5 and Euro 6) and on access to vehicle repair and maintenance information.

[2] United Nations Economic Commission for Europe, Addendum 82: Regulation No. 83, last updated 26.04.2011.

[3] Bielaczyc P.: Development of automotive fuels and fuel test methods in response to new emissions reduction and $\mathrm{CO} 2$ legislation. Euro Oil \& Fuel Conference, Krakow, Poland, 24 November 2010.

[4] De Filippo A.: Particle Size and Number Emissions from Modern Light-Duty Diesel Vehicles. SAE paper 2011-01-0632, 2011.

[5] System 1 instruction manual, as provided by the manufacturer.

[6] System 2 instruction manual, as provided by the manufacturer.

[7] Giechaskiel B., Dilara P., Sandbach E., Andersson J.: Particle measurement programme (PMP) light-duty inter-laboratory exercise: comparison of different particle number measurement systems. Meas. Sci. Technol. 19 (2008) 095401, 2008.
[8] TSI 3790 CPC Instruction manual.

[9] ACEA Diesel Vehicle Particle Number Round Robin Test, UTAC test report 09/00003, 2009. Available online: ec.europa. eu/transport

[10] Bielaczyc P., Szczotka A., Pajdowski P., Woodburn, J.: Development of vehicle exhaust emission testing methods - BOSMAL's new emission testing laboratory. Combustion Engines, 1/2011 (144), 2011.

[11] Kirchner U., Vogt R., Maricq M.: Investigation of EURO-5/6 Level Particle Number Emissions of European Diesel Light Duty Vehicles. SAE paper 2010-01-0789, 2010.

[12] Chiou M.C.: Effect of thermophoresis on submicron particle deposition from a forced laminar boundary layer flow onto an isothermal moving plate. Acta Mechanica, 129, 3-4, 219-229, 1998.

[13] Montassier N., Boulaud D., Renoux A.: Experimental study of thermophoretic particle deposition in laminar tube flow. Journal of Aerosol Science, 22, 5, 677-687, 1991.

\section{Abbreviations/Skróty i oznaczenia \\ PMP Particulate measuring protocol/zasady pomiaru czastek \\ PM Particulate matter/czastki stałe \\ PN Particulate number/liczba czastek statych \\ EU European Union/Unia Europejska \\ CI Compression ignition/zaplon samoczynny \\ DPF Diesel particulate filter/filtr czastek stalych \\ PPM Parts per million/czastek na milion \\ CPC Condensation particle counters/licznik kondensacyjny czastek statych}

Piotr Bielaczyc, DEng. - head of the Engine Research Department, BOSMAL Automotive Research and Development Institute Ltd in Bielsko-Biała.

Dr inż. Piotr Bielaczyc - kierownik Zakładu Badań Silników, Instytut Badań i Rozwoju Motoryzacji BOSMAL Sp. z o.o., Bielsko-Biata.

e-mail:piotr.bielaczyc@bosmal.com.pl

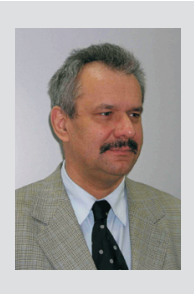

Prof. Jerzy Merkisz, DSc., DEng. - Professor in the Faculty of Working Machines and Transportation at Poznan University of Technology.

Prof. Jerzy Merkisz - profesor na Wydziale Maszyn Roboczych i Transportu Politechniki Poznańskiej.

e-mail: jerzy.merkisz@put.poznan.pl

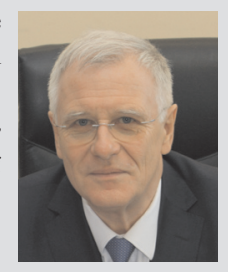

NEDC New european driving cycle/nowy europejski cykl jezdny

LDV Light duty vehicle/lekki samochód użytkowy

PTS Particle transfer system/system przeplywu czastek statych

VPR Volatile particle reductor/reduktor (odparowywacz) lotnych czastek

PND Particulate number diluters/przewody rozcieńczania spalin

ET Evaporation tube/przewód do odparowania

Piotr Pajdowski, DEng. - doctor in the Engine Research Department, BOSMAL Automotive Research and Development Institute Ltd in Bielsko-Biała.

Dr inż. Piotr Pajdowski-adiunkt w Zaktadzie Badań Silników, Instytut Badań i Rozwoju Motoryzacji BOS MAL Sp. z o.o., Bielsko-Biała.

e-mail:piotr.pajdowski@bosmal.com.pl

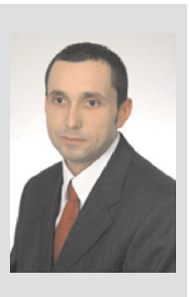

Joseph Woodburn, MSc. - researcher at the Engine Research Department, BOSMAL Automotive Research and Development Institute Ltd in Bielsko-Biała.

Mgr inż. Joseph Woodburn - inżynier ds. badań w Zakładzie Badań Silników, Instytut Badań i Rozwoju Motoryzacji BOSMAL Sp. z o.o., Bielsko-Biała. 